\title{
PERSPECTIVES OF THE USE OF COMMISSURE IN PATIENTS WITH OBLIQUE FRACTURES OF THE LOWER JAW
}

\author{
(C) Y. Efimov, D. Stomatov, E. Efimova, A. Stomatov, V. Borodin \\ Проведен анализ результатов лечения 34 больных с косым переломом нижней челюсти различной локали- \\ зации. Остеосинтез выполняли посредством костного шва по разработанной авторами методике. \\ Способ заключается в формировании на большем отломке площадки с уступом, что позволяет устранить \\ горизонтальное смещчение, укорочение зубной дуги, деформаџию лица. Послеоперационный период у боль- \\ ных протекал без осложнений, что позволяет рекомендовать данный способ к иирокому использованию в \\ клинической практике
}

Ключевые слова: перелом нижней челюсти, вывих головки, смещение отломков, остеосинтез, костньй шов

There was carried out an analysis of the results of treatment of 34 patients with oblique fractures of the lower jaw by the method of commissure osteosynthesis that was elaborated by the authors.

Aim: to increase the effectiveness of treatment of patients with oblique fractures of the lower jaw at the expense of optimization of commissure osteosynthesis.

Methods: there was carried out examination and operative treatment of 34 patients with oblique fractures of lower jaw of the different localization. In the area of the lower jaw angle-19 (55,88\%) patients, in the area of the lower jaw body-12 (35,29\%) persons, the number of patients with fractures of the neck with dislocation of the head of lower jaw was $3(8,83 \%)$. All patients were the persons of male sex 32-55 years old. The operative treatment was consisted in commissure osteosynthesis according to the method elaborated by the authors.

Results: there were not observed any complication in operated patients during postoperative period. There were not observed the secondary displacement of splinters or inflammatory complications. The consolidation of splinters was clinically observed on 21 day after operation. In remote terms ( 3 month after osteosynthesis) patients have no complaints the disorders of dental occlusion did not take place.

\section{Conclusions:}

An offered method of osteosynthesis with wire suture allows:

1. Eliminate the horizontal displacement of splinters;

2. Eliminate the shortening of the jaw arch and the deviation of occlusion with deformation of the patient's face;

3. Raise the stability of osteosynthesis.

The remote results testify the high effectiveness of the method that allows recommend it for the wide use in clinical practice

Keywords: lower jaw fracture, head dislocation, splinter displacement, osteosynthesis, commissure

\section{Introduction}

The treatment of patients with lower jaw fractures remains one of the topical problems of the oral surgery. In the structure of traumatism this pathology stands on the particular position because of both functional and cosmetic disorders. It worth to notice that last years takes place the tendency not only to growth of the number of patients with fractures of facial bones but also to the weighting of the character of trauma first of all at the expense of multiple fractures and associated disorders. According to the national and foreign clinics the lower jaw fractures consist $70-85 \%$ from all injuries of the facial skeleton [1-4].

Among the different methods of fixation of the lower jaw splinters the leading role play orthopedic ones. But it not also guarantees the accurate reposition of splinters and its stable fixation for all consolidation period especially if fracture is localized in the area of lower jaw angle. At the same time the constant fixation of the lower jaw in the forced position results in dysfunctional disorders in temporal and lower jaw joint $[5,6]$. That is why many authors prefer surgical methods as the most effective in the aspect of guaranteeing stability of the splinters.

\section{Substantiation of research}

Commissure remains the most widespread type of osteosynthesis. At the same time information from the scientific literature testify the ambiguous attitude of researchers to this method $[3,4]$. The main shortcoming of osteosynthesis is hanging of the large fragment down with appearance of the false triangular form defect in the area of alveolar part of lower jaw. The aforesaid shortcoming can be excluded at suture the intraoral commissure on the walls of distant alveolar sockets. But the firmness of this osteosynthesis is smallish and needs an additional fixation. Oblique fractures are the absolute contraindication to the use of commissure because of overlay of splinters on each other at twisting of the wire $[2,5,7-9]$

Today osteosynthesis with titanic mini-plates is widely used at the oblique fractures of the lower jaw $[10,11]$. But as several authors argue $[2,7,8]$ at oblique 
fractures its stability is often insufficient that is connected with the different thickness of the compact bone on the tongue side of jaw and this in its turn not always allows to fix the mini-screw in it securely and may result in displacement of splinters in the dynamic of postoperative period.

\section{Aim of research}

To raise effectiveness of treating patients with oblique fractures of the lower jaw at the expense of optimization of osteosynthesis with commissure.

\section{Material and methods}

The work was carried out on the base of maxillofacial surgery department of Penza State University and maxillofacial surgery department of N. N. Burdenko Region Clinical Hospital. Under our observation were 34 patients with oblique fractures of lower jaw of the different localization. In the area of lower jaw angle $19(55,88 \%)$ patients, in the area of lower jaw body $12(35,29 \%)$ persons, and $3(8,83 \%)$ persons with fractures of neck of the lower jaw head. All patients were persons of male sex 32-55 years old.

The essence of offered methods is in formation on the big splinter the area with ledge that allow to exclude completely the overlay of splinters ends on each other that results in shortening of this half of jaw and deviation of occlusion with deformation of patient's face and also hanging of the big splinter down and appearance of the false triangle form defect (Patent RF № 2565818).

This method is realized in the following way.

The surgery is carried out under general anesthesia. After dissection of the soft tissues and elimination of the muscle interposition in the spongy layer of the big (relative to the fissure of fracture) splinter on all plane of fracture is formed the area with depth not more than 0,1 sm. at the same time an untouched cortical layer serves as a support for the small (relative to the fissure of fraction) splinter (Fig. 1, $a, b$ ) that after reposition is placed on the area, then in every splinter with indent of $0,75 \mathrm{sm}$. and $1,5 \mathrm{sm}$. from the lower edge of lower jaw are formed two through channels that conduct the wire ligature which free ends are twisted on the external surface of the lower jaw and then the wound is sutured layer-by-layer.

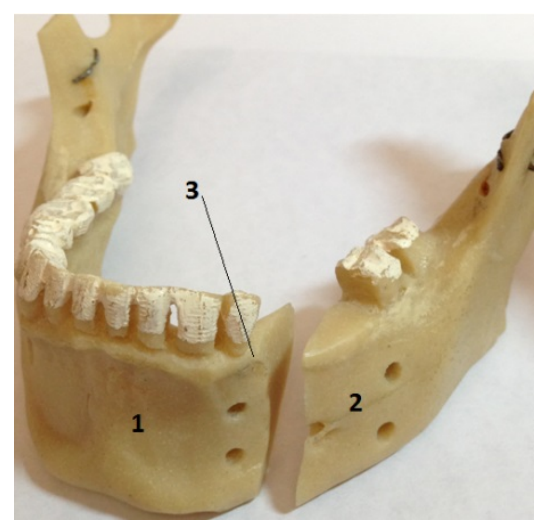

$a$

\section{Results of research}

In all operated patients the healing of wound was realized at the primary intention on 7 day after surgery. The further postoperative period ran without complications. There were not observed the secondary displacement of splinters and the inflammatory complications. Clinically the consolidation of splinters was observed on 21 day after surgery. In remote terms (3 month after osteosynthesis) there were no complaints from patients, the deviation of occlusion was not observed.

Clinical example. Patient K. 30 years old was admitted to hospital with the oblique fracture of the neck of the condylar process of the lower jaw with dislocation of its head (Fig. 2).

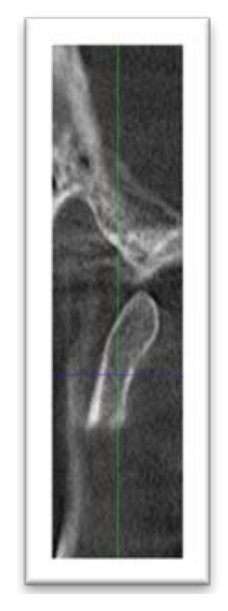

$a$

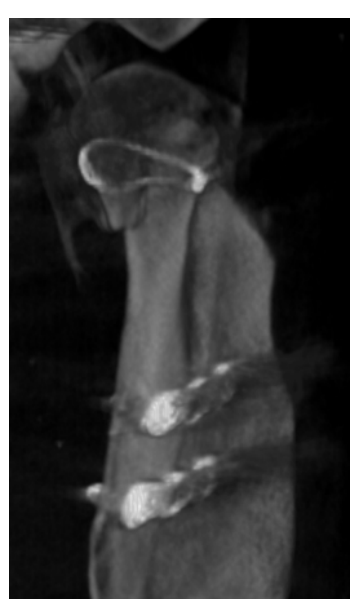

$b$
Fig.2. Photo of patient's K. 3D x-ray picture: $a$ - before surgery; $b$ - in 3 month after surgery

The skeletonization and the oblique osteotomy of the lower jaw branch with elimination of its head were carried out according to traditional method. On the osteotomized fragment in the spongy bone was formed an area 1 with ledge of compact bone 2 (Fig. 3,a) and on this area was placed the head of lower jaw and fixed with commissure (Fig. 3, b).

Then the osteotomized fragment was fixed to the lower jaw branch with two mini-plates and after this the wound was sutured layer-by-layer.

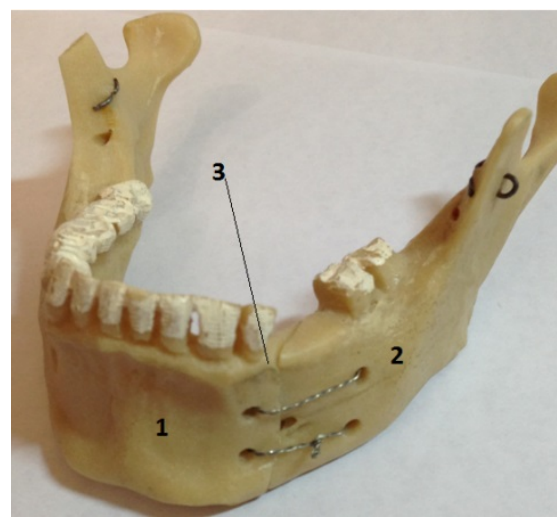

$b$

Fig. 1. Method of commissure (scheme): $a$ - before splinters fixation; $b$ - after splinters fixation; 1 - big splinter, 2 small splinter, 3 - compact bone ledge 


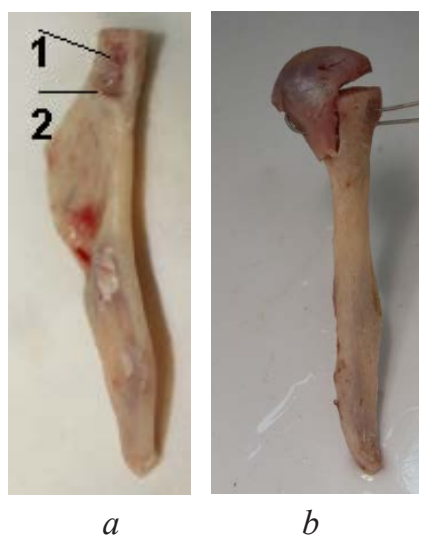

Fig. 3. Photos of osteotomized fragment of the patient's K. lower jaw branch: $a$ - fragment of the lower jaw branch with formed area 1 and ledge $2 ; b$ - the head of lower

jaw placed on the area and fixed with commissure

Postoperative period ran without any complications. The control examination and computed tomography were carried out in three month after surgery. There were not observed any functional disorders of the lower jaw and any displacements of splinters (Fig. 2, b).

\section{Discussion of the results of research}

The results demonstrated that the formation of area with ledge on the big splinter at oblique fractures of lower jaw allows use the method of osteosynthesis with wire suture attaining the firm fixation of bone splinters. Examination and control tomography data received in remote terms testify the absence: of the deformation of face, deviation of occlusion, displacement of bone splinters.

\section{Conclusions}

The offered method of osteosynthesis with wire suture allows:

1. Eliminate the horizontal displacement of splinters;

2. Eliminate the shortening of jaw arch and deviation of occlusion with deformation of patient's face;

3. Raise the stability of osteosynthesis.

The remote results testify the high effectiveness of this method that allow recommend it for the wide use in clinical practice.

\section{References}

1. Dolgova, I. V. Prevention of traumatic osteomyelitis of the mandible [Text]: auth. dis. ... cand. of med. sci. / I. V. Dolgova. - Volgograd, 2013. -21 p.

2. Efimov, Y. V. Surgery of the teeth and oral cavity guidance [Text] / Y. V. Efimov, Y. V. Efimov, V. R. Golbraikh, H. H. Mukhaev, P. V. Ivanov, E. Yu. Efimova. - Moscow, 2010. - 136 p.

3. Kitshoff, A. M. A retrospective study of 109 dogs with mandibular fractures [Text] / A. M. Kitshoff, H. de Rooster, S. M. Ferreira, G. Steenkamp // Veterinary and Comparative Orthopaedics and Traumatology. - 2012. - Vol. 26, Issue 1. - P. 1-5. doi: $10.3415 /$ vcot-12-01-0003

4. Payne, K. F. A review of trauma and trauma-related papers published in the British Journal of Oral and Maxillofacial Surgery in 2010-2011 [Text] / K. F. B. Payne, A. Tahim,
A. M. C. Goodson, S. Colbert, P. A. Brennan // British Journal of Oral and Maxillofacial Surgery. - 2012. - Vol. 50, Issue 8. P. 769-773. doi: 10.1016/j.bjoms.2012.09.003

5. Telnih, J. R. The Use of biologically active preparations in prevention of complications in treating patients with traumatic open fractures of the mandible [Text] / J. R. Telnih // Dentistry. - 2008. - Issue 4. - P. 56-58.

6. Bouloux, G. F. Small and large titanium plates are equally effective for treating mandible fractures $[$ Text $] /$ G. F. Bouloux, S. Chen, J. M. C. Threadgill // Journal of Oral and Maxillofacial Surgery. - 2012. - Vol. 70, Issue 7. - P. 1613-1621. doi: 10.1016/j.joms.2012.02.029

7. Efimov, E. Y. Dimensional characteristics of the front section of the mandible [Text] / E. Y. Efimov, A. I. Krayushkin, V. Efimov, N. V. Shabanova // Pacific medical journal. - 2014. Issue 3. - P. 30-32.

8. Sergeev, S. C. In view of strength characteristics of facial bones in operation planning [Text] / S. C. Sergeev, P. C. Ivanov, E. C. Grigorishin // Bulletin of new medical technologies. 2013. - Vol. 20, Issue 2. - P. 212-216.

9. Zulkina, L. A. Sexual dimorphism odontometrics characteristics of the residents of the Penza region 21-36 years depending on the parameters of the cranio-facial complex [Text]: abs. of thes. ... cand. of med. sci. / L. A. Zulkina. - Volgograd, 2011. $-23 \mathrm{p}$.

10. Ellis, E. Open reduction and internal fixation of combined angle and body/symphysis fractures of the mandible: how much fixation is enough? [Text] / E. Ellis // Journal of Oral and Maxillofacial Surgery. - 2013. - Vol. 71, Issue 4. - P. 726-733. doi: 10.1016/j.joms.2012.09.017

11. Gokkulakrishnan, S. An analysis of postoperative complications and efficacy of 3-D miniplates in fixation of mandibular fractures [Text] / S. Gokkulakrishnan // Dent. Res. J. 2012. - Vol. 9, Issue 4. - P. 414-421.

\section{References}

1. Dolgova, I. V. (2013). Prevention of traumatic osteomyelitis of the mandible. Volgograd, 21.

2. Efimov, Y. V., Efimov, Y. V., Golbraikh, V. R., Mukhaev, H. H., Ivanov, P. V., Efimova, E. Yu. (2010). Surgery of the teeth and oral cavity guidance. Moscow, 136.

3. Kitshoff, A. M., de Rooster, H., Ferreira, S. M., Steenkamp, G. (2012). A retrospective study of 109 dogs with mandibular fractures. Veterinary and Comparative Orthopaedics and Traumatology, 26 (1), 1-5. doi: 10.3415/vcot-12-01-0003

4. Payne, K. F. B., Tahim, A., Goodson, A. M. C., Colbert, S., Brennan, P. A. (2012). A review of trauma and trauma-related papers published in the British Journal of Oral and Maxillofacial Surgery in 2010-2011. British Journal of Oral and Maxillofacial Surgery, 50 (8), 769-773. doi: 10.1016/j.bjoms.2012.09.003

5. Telnih, J. R. (2008). The Use of biologically active preparations in prevention of complications in treating patients with traumatic open fractures of the mandible. Dentistry, 4, 56-58.

6. Bouloux, G. F., Chen, S., Threadgill, J. M. C. (2012). Small and Large Titanium Plates Are Equally Effective for Treating Mandible Fractures. Journal of Oral and Maxillofacial Surgery, 70 (7), 1613-1621. doi: 10.1016/j.joms.2012.02.029

7. Efimov, E. Y., Krayushkin, A. I., Efimov, V., Shabanova, N. V. (2014). Dimensional characteristics of the front section of the mandible. Pacific medical journal, 3, 30-32. 
8. Sergeev, S. C., Ivanov, P. C., Grigorishin E. C. (2013). Accounting for the strength characteristics of the facial bones when planning surgical interventions. Bulletin of new medical technologies, 20 (2), 212-216.

9. Zulkina, L. A. (2011). Sexual dimorphism odontometrics characteristics of the residents of the Penza region 21-36 years depending on the parameters of the cranio-facial complex. Volgograd, 23.
10. Ellis, E. (2013). Open Reduction and Internal Fixation of Combined Angle and Body/Symphysis Fractures of the Mandible: How Much Fixation Is Enough? Journal of Oral and Maxillofacial Surgery, 71 (4), 726-733. doi: 10.1016/ j.joms.2012.09.017

11. Gokkulakrishnan, S. (2012). An analysis of postoperative complications and efficacy of 3-D miniplates in fixation of mandibular fractures. Dent. Res. J., 9 (4), 414-421.

Дата надходження рукопису 12.01.2016

Efimov Yuri, Doctor of medical Sciences, Professor, Department of maxillofacial surgery and surgical dentistry, Volgograd State Medical University, Fallen Fighters squ., 1, Volgograd, Russia, 400131

Stomatov Dmitry, Assistant, Department of oral and maxillofacial surgery, Penza State University, Krasnaya str., 40, Penza, Russia, 440026

Efimova Evgeniya, Candidate of medical Sciences, Associate Professor, Department of human anatomy, Volgograd State Medical University, Fallen Fighters sq., 1, Volgograd, Russia, 400131

Stomatov Alexander, Candidate of medical Sciences, associate Professor, Department of dentistry, Penza State University, Krasnaya str., 40, Penza, Russia, 440026

Borodin Valery, Maxillofacial surgeon, Department of oral and maxillofacial surgery, Penza regional clinical hospital named after Burdenko N. N., Lermontova str., 28, Penza, Russia, 440026

УДК 616.72-002-021.5-07: [616.34-008.87+612.017]-053.2

DOI: $10.15587 / 2313-8416.2016 .61080$

\section{ВЗАИМОСВЯЗЬ ПОКАЗАТЕЛЕЙ МИКРОБИОЦЕНОЗА КИШЕЧНИКА И МЕСТНОГО ИММУНИТЕТА У ДЕТЕЙ, БОЛЬНЫХ РЕАКТИВНЫМИ АРТРИТАМИ}

\section{(C) Т. А. Твердохлеб}

В данной работе определень частота и степень нарушений микробиоценоза кишечника и состояние местного иммунитета (секреторный иммуноглобулин А) у детей больных реактивныли артритами (РеА) в остром периоде и через 9-12 месяиев от начала заболевания. Выявлена достоверная прямая связь уровня секреторного иммуноглобулина А со степенью дисбиоза. Секреторный иммуноглобулин А следует рассматривать как один из прогностических факторов, влияющих на течение реактивного артрита

Ключевые слова: реактивный артрит, дети, микробиоценоз кишечника, условно-патогенная флора, секреторный иммуноглобулин $A$

Aim. To improve the diagnostics and prognostication of ReA clinical course in children on the base of study of intestinal microflora and the local immunity (secretory immunoglobulin A (sIgA)).

Materials and methods. There were examined 40 children with ReA in an acute period in 9-12 month after the beginning of disease. 23 healthy children formed the control group. The examination of children was carried out in municipal children cardiorheumatologic department of CIHP "Kharkov municipal children clinical hospital № 24” and Kharkov municipal children polyclinics (№ 1, 2, 7, 12, 13, 14, 23). ReA diagnosis was set according to the order of MHP of Ukraine from 19.07.2005 № 362 «Report on diagnostics and treatment of diseases of musculoskeletal system and connective tissue in children MKX-X M00-M25 arthropathy».

The definition of the degree of disorder of large intestinal microbiocoenosis was carried out on the base of the order of MHP of Ukraine from 29.01.2013 №59 «Unified clinical report on medical help for children with diseases of alimentary organs».

The sIgA definition is based on the use of "sandwich"-variant of hardphase immune-enzyme analysis. The study was carried out using the laboratory set of reagents for immune-enzyme definition of secretory IgA in biological liquids «Secretory IgA-IEA» LLC «HEMA» (№ FSR 2009/06385 from 16 of December 2009 year).

An assessment of results of the studies was carried out using the STATISTICA program for Windows (10.0 version), Microsoft Excel 2012, MATLAB 2015 a. 